Editorial Manager(tm) for International Journal of Science and Mathematics Education Manuscript Draft

Manuscript Number:

Title: Understanding acid-base concepts: Evaluating the efficacy of a senior high school studentcentred instructional program

Article Type: Original Full Paper

Keywords: constructivist approach, context-based approach, inquiry approach, intrinsic motivation, perceptions, student achievement, student-centred instruction, teaching effectiveness.

Corresponding Author: MS SRI RAHAYU, Master

Corresponding Author's Institution: State University of Malang

First Author: SRI RAHAYU, Master

Order of Authors: SRI RAHAYU, Master; A.L Chandrasegaran, Dr; David F Treagust, Dr; Masakazu Kita, Dr; Suhadi Ibnu, Dr

Abstract: This study was a mixed quantitative-qualitative research to evaluate the efficacy of a designed student-centred instructional program (DSCI) for teaching about acids and bases. The teaching innovation was designed based on constructivist, hands-on inquiry, and context-based approaches and implemented in seven 45-minute lessons with a class of 36 grade 11 students (experimental group) from a public senior high school in Indonesia. Another class of 38 students (comparison group) from the same school were instructed using a traditional teacher-centred approach. Data were obtained using a (1) 12-item achievement test on acids and bases that was administered to both groups as a pretest and a posttest, (2) self-evaluation 13-item questionnaire on students' perceptions of their competence and confidence in carrying out the inquiry activities that was administered to the experimental group, and (3) 3-item open-ended questionnaire on students' perceptions of the instructional process using the DSCI that was administered to the experimental group. The results of the study showed that the teaching innovation was effective in improving students' understanding of acid-base concepts with significant difference between the two groups on the posttest mean scores. Moreover, the effectiveness of the innovation was supported by an increase in students' intrinsic motivation as indicated by their (1) positive perceptions of their engagament and competence in doing inquiry activities, (2) positive perceptions of the learning environment, and (3) positive outcome expectations. The findings have implications for chemistry teaching in any institution with similar achieving students as well as for the professional development of teachers. 


\section{Contact Detail}

Authors:

\section{Sri Rahayu ${ }^{\mathrm{a}_{*}}$,}

*Corresponding author.

Department of Chemistry, Faculty of Mathematics \& Science, State University of Malang, Jl. Semarang 5 Malang Indonesia 65145.

Email: srirahayu_um@hotmail.com

\section{A.L Chandrasegaran ${ }^{b}$,}

${ }^{\mathrm{b}}$ Science and Mathematics Education Centre, Curtin University of Technology, Perth, Australia.

Email: a.chandrasegaran@exchange.curtin.edu.au

\section{David F. Treagust ${ }^{b}$,}

${ }^{\mathrm{b}}$ Science and Mathematics Education Centre, Curtin University of Technology, Perth, Australia.

Email: d.treagust@curtin.edu.au

\section{Masakazu Kita ${ }^{c}$}

${ }^{\mathrm{c}}$ Natural Science Department, Faculty of Education, Okayama University, Okayama, Japan

Email:kitam@cc.okayama-u.ac.jp

\section{Suhadi Ibnu ${ }^{\mathrm{a}}$}

Department of Chemistry, Faculty of Mathematics and Science, State University of Malang, Malang, Indonesia

Email: suhadi_ibnu2007@yahoo.com 


\title{
Understanding acid-base concepts: Evaluating the efficacy of a senior high school student-centred instructional program
}

\begin{abstract}
This study was a mixed quantitative-qualitative research to evaluate the efficacy of a designed student-centred instructional program $(D S C I)$ for teaching about acids and bases. The teaching innovation was designed based on constructivist, hands-on inquiry, and context-based approaches and implemented in seven 45-minute lessons with a class of 36 grade 11 students (experimental group) from a public senior high school in Indonesia. Another class of 38 students (comparison group) from the same school were instructed using a traditional teachercentred approach. Data were obtained using a (1) 12-item achievement test on acids and bases that was administered to both groups as a pretest and a posttest, (2) self-evaluation 13-item questionnaire on students' perceptions of their competence and confidence in carrying out the inquiry activities that was administered to the experimental group, and (3) 3-item open-ended questionnaire on students' perceptions of the instructional process using the DSCI that was administered to the experimental group. The results of the study showed that the teaching innovation was effective in improving students' understanding of acid-base concepts with significant difference between the two groups on the posttest mean scores. Moreover, the effectiveness of the innovation was supported by an increase in students' intrinsic motivation as indicated by their (1) positive perceptions of their engagament and competence in doing inquiry activities, (2) positive perceptions of the learning environment, and (3) positive outcome expectations. The findings have implications for chemistry teaching in any institution with similar achieving students as well as for the professional development of teachers.
\end{abstract}


Keywords: constructivist approach, context-based approach, inquiry approach, intrinsic motivation, perceptions, student achievement, student-centred instruction, teaching effectiveness

\section{Introduction}

Results of the Third International Mathematics and Science Study (TIMSS) and the Program for International Student Assessment (PISA) indicate that Indonesian students' performance in mathematics and science is relatively poor compared to students in other developing countries (Gonzales, Calsyn, Jocelyn, Mak, Kastberg, Arafeh, Williams, \& Tsen, 2000; Lemke, Sen, Pahlke, Partelow, Miller, Williams, Kastberg, \& Jocelyn, 2004). This is one of the reasons why the the Indonesian government is keen to reform science education. The essence of the revamping of the science education program lies in the implementation of a decentralized educational system, implementation of a competence-based curriculum and reform of the learning paradigm (Sidi, 2008). One of the government's reform initiatives was to launch a new curriculum in 2006. The new 2006 curriculum suggests that the pedagogy implemented in all school levels should be student-centred with an emphasis on creativity, competency, life skills, and hands-on experiences (BNSP: National Education Standards Agency, 2007). Consequently, primary, middle, and secondary school science teachers are expected to to create learning environments that facilitate students' construction of science understandings, skills, and attitudes. Several efforts have been made to realize such curricular expectations. For example, the educational community and researchers have introduced a contextual teaching and learning (CTL) approach as well as an active, creative, and enjoyable teaching and learning approach (PAKEM in the Indonesian language) in efforts to reform instruction in schools in line with the expectations of the BSNP (2007). However, such reforms have been difficult to implement at the high school level because traditional instruction in science, including 
chemistry, at the high school level in Indonesia is mainly lecture-based. Students generally conduct chemistry laboratory activities in a very structured environment in order to verify the expected results that are indicated in the textbook or by the instructor.

\section{Theoretical background}

\section{Constructivist approach}

Research in science education over the past three decades or so has been dominated by the constructivist perspective of learning. According to this perspective, meaningful learning does not involve mere passive absorption of information, but rather, involves the active creation and modification of knowledge structures (Carey, 1985). In other words, the learner is a responsible, active agent in his/her knowledge acquisition process (Loyens \& Gijbels, 2008). Learning is considered as an individual process that involves connecting new ideas and experiences to prior knowledge through interactions with the physical and/or social environment (Liang \& Gabel, 2005). Basically, this perspective stresses the thought processes of the learner and assumes that prior knowledge, attitude, motivation, and learning style affect the learning process (Spencer, 1999).

\section{Inquiry approach}

The school science curriculum has generally been characterized as consisting aspects of scientific content and scientific processes (Bass, Constant, \& Carin, 2009). The content consists of statements about nature, including natural entities, and the theories and concepts used to understand and explain these entities. Process refers to the practices by which scientific knowledge is developed, involving the interplay of experiment, prediction, hypothesis generation, and communication of results within a scientific community. Within such a curriculum, students are expected to learn the content of science as well as experience its processes. 
A connection of scientific processes and learning of content through 'inquiry' is already well recognized and is implemented in many countries (Abd-El-Khalick, Boujaoude, Duschl, Lederman, Mamlok-Naaman, Hofstein, Niaz, Treagust, \& Tuan, (2004). Inquiry instruction supports the constructivist approach to learning science (Bass, Constant \& Carin, 2009). According to the National Science Education Standards (NSES) in the US (NRC, 1996), scientific inquiry describes the diverse ways in which scientists study the natural world and propose explanations based on the evidence derived from their work. Inquiry also refers to the activities of students in which they develop knowledge and understanding of scientific ideas, as well as an understanding of how scientists study the natural world. Therefore, providing students with authentic opportunities to conduct scientific inquiries is expected to enhance their abilities to successfully evaluate complex scientific ideas. Conversely, a lack of experience with scientific inquiry restricts the success with which students are able to evaluate scientific knowledge claims (Trumbull, Bonney \& Grudens-Schuck, 2005).

Learning outcomes associated with inquiry dimensions of science include generating a hypothesis, developing a plan for gathering data, and constructing arguments based on evidence. Through the practice of inquiry, students acquire knowledge in a more meaningful way (Germann, Haskins, \& Auls, 1996) but do need ample opportunities to practise science processes by conducting a variety of investigations. Together with appropriate feedback and modeling, students should become more proficient and independent. If teachers and students connect the domain-specific contexts of the laboratory with more general contexts, then students will be able to apply the science processes outside the classroom (Germann \& Aram, 1996).

\section{Context-based approach}

The notion of a context-based approach comes from recent attempts to reform the design of courses in chemical education in order to address a number of inter-related problems. Context 
here is used as the basis for curriculum design and classroom teaching (Gilbert, 2006; Schwartz, 2006). According to Pearsall (1999), context refers to the circumstances of an event, statement, or idea, and the terms in which it can be fully understood. A context must provide a coherent structural meaning for something new that is set within a broader perspective. This description is consistent with the function of the use of contexts in chemical education in that students should be able to provide meaning to the learning of chemistry and should be able to connect the subject matter to some aspect of their lives. Students should be able to construct coherent mental maps of the subject. Findings from research into context-based curricula suggest that (1) students' interest and enjoyment of their science lessons generally increase when they use context-based materials and follow context-based courses, (2) context-based materials help students to see and appreciate more clearly links between the science they study and their everyday lives, and (3) students following context-based instruction learn science concepts at least as effectively as those following the more traditional instruction (Gilbert, 2006).

\section{Students' motivation to learn}

In addition to students' cognitive achievement, students' motivation (i.e., intrinsic motivation) is an important aspect for evaluating the effectiveness of a teaching innovation. Palmer (2009) defines motivation as any process that innitiates and maintains learning behaviour and is an essential prerequisite and co-requisite for learning. In this sense, motivation is required initially to make students want to participate in learning and is then needed throughout the whole learning process. According to constructivist theory, students should make an effort in their learning, and in turn be motivated to learn in a meaningful manner.

In the motivational literature, motivation has been conceptualized in a variety of ways. According to Pintrich and DeGroot (1990) motivation has three components: (1) an expectancy component (e.g., self-efficacy, attributional style, and comparison beliefs), (2) a value component (e.g., learning vs. performance goals, intrinsic vs. extrinsic orientation, task 
value, and intrinsic interest), and (3) an affective component (e.g., anger, pride, guilt). The basic construct of the expectancy component of student motivation involves students' beliefs that they are able to perform the task and that they are responsible for their own performance. In this sense, the expectancy component involves students' answers to the question, "Can I do this task?" The value component of student motivation involves students' goals for the task and their beliefs about the importance and interest of the task. This motivational component essentially concerns students' reasons for doing a task. In other words, this component requires answers to the question, "Why am I doing this task?" The third motivational component concerns students' affective or emotional reactions to the task. The important issue for students involves the question, "How do I feel about this task?"

In this study, students' motivation can be discerned through students' reports on their beliefs and behaviour such as beliefs on their level and quality of task engagement, judgment on their capabilities to perform a task, beliefs about the utility of a course, and personal interest in course materials (Zusho, Pintrich, \& Coppola, 2003).

\section{Objectives and research questions of the study}

Limitations of learning science in the absence of inquiry experiences are well known. When science is presented as a body of knowledge, students are discouraged from developing their own explorations and explanations of observed phenomena (Trumbull et al., 2005). In this study, an innovative science instructional program was designed for the topic of acids and bases to fulfill the expectations of the new 2006 chemistry curriculum. The Designed StudentCentred Instruction (DSCI) on acids and bases is a teaching-learning sequence oriented toward contemporary chemical education approaches. It includes the use of hands-on, inquiry-oriented and collaborative activities connected to students' everyday life experiences and environmental issues. According to Wise (1996), any innovative instruction should be a mixture of teaching 
strategies, and no one strategy is as powerful as a combined approach. If students are placed in an environment in which they can actively connect the instruction to their interests and present understanding and have an opportunity to experience collaborative scientific inquiry under the guidance of an effective teacher, their achievements are likely to be enhanced. Therefore, this study examines whether or not the $D S C I$ was more effective in teaching concepts about acids and bases than the traditional instruction. To further understand the effect of the innovative instruction, some aspects of learning are examined, such as students' cognitive achievement, students' perceptions of their competence and confidence in inquiry activities and students' perceptions of the teaching-learning process.

In this study, the following research questions are investigated:

1. Is the teaching innovation on acids and bases more effective in increasing students' cognitive achievement than traditional instruction?

2. What are students' perceptions on their engagement and competence in doing inquiry activities in the teaching innovation on acids and bases?

3. What are students' perceptions of the instructional process in the teaching innovation on acids and bases?

\section{Methodology}

\section{Research design}

This study incorporated both quantitative and qualitative research (Tashakkori \& Teddlie, 2003) with an intervention instructional program that was conducted over seven lessons, each lasting 45 minutes. Quantitative data were collected using an achievement test on acids and bases as a pretest and a posttest that were administered to the experimental and comparison groups prior to commencing the intervention program and on completion of the program. Other quantitative data were obtained from a self-evaluation questionnaire on students' perceptions of 
their competence and confidence in inquiry activities, administered to the experimental group on completion of the intervention program. In addition, qualitative data were collected using an open-ended questionnaire on students' perceptions of the teaching-learning process that was administered to the experimental group at the end of the intervention program. The diverse range of data collected enabled the triangulation of the data in order to ascertain whether or not the results supported or contradicted each other (Creswell, 2008).

\section{Participants}

The study involved two groups of 11th grade students - an experimental group and a comparison group - chosen from the same public senior high school located in Malang, Indonesia. The experimental group comprised 36 students (13 boys, 23 girls) and the comparison group comprised 38 students (13 boys, 25 girls). The students from both groups came from similar socioeconomic backgrounds with achievement levels about average for the country.

\section{Classroom instruction on acids and bases}

The educational system that prevails in Indonesia dictates the curriculum in which all students follow the same syllabus. Thus, all students study the concept of acids and bases in the 11th grade. Both the experimental and comparison groups that participated in the study learned the basic concepts of acids and bases required by the school curriculum. These concepts were (1) characteristics of acids and bases, (2) definition of acids and bases, (3) strength of acids and bases, (4) neutralization, and (5) $\mathrm{pH}$. The experimental group was taught by a teacher (one of the researchers) while the comparison group was taught by a chemistry teacher from the school. Both teachers had similar teaching experience and educational backgrounds. The researchers were aware of the limitation of the different teachers teaching in comparison and experimental classes - this difference may itself influence student learning. Therefore, to minimize this effect on the results of this study and to verify the effectiveness of the treatment, throughout 
this study a researcher observed the comparison and experimental groups and took field notes to ensure that both teachers followed the intended lesson plans in their respective classes.

The two groups followed the same basic syllabus and used the same textbook. The contents of the topic on acids and bases were taught to both groups in the same order. Moreover, the same length of time (i.e., seven 45-minute class periods) was devoted to teaching the topic. The only difference between the two groups was that the experimental group was taught using the DSCI on acids and bases, while the teaching-learning process implemented with the comparison group was direct instruction with a textbook-based approach in which laboratory activities were conducted in 'cookbook' fashion primarily to confirm concepts that had been learned in the classroom.

The intervention program: The DSCI on acids and bases

The DSCI on acids and bases that was implemented with the experimental group incorporated a number of strategies that form the core of contemporary thinking about science education reform. These include a constructivist approach, a hands-on inquiry approach, and a context-based approach. The following teaching sequence was implemented with the experimental group in each of the seven lessons.

Phase 1. Introduction. Each lesson was initiated by presenting a concept map, used as an advance organizer, to clearly show the connection between the concepts within the topic and to facilitate learning (Berg, 2006; Hughes \& Hay, 2001). Students were next shown some examples of materials used in their daily lives. This activity was intended to make students aware that there is a connection between what they learn in the classroom and their everyday experiences, and to engage students' attention and enthusiasm for the next activity in phase 2 .

Phase 2. Hands-on inquiry activity. In this activity, students were given direct experiences of engaging in the exploration of acids and bases by using a fourth level of inquiry which according to LeRoy and Lee (2008) involved five consecutive steps (i.e., questionning, 
planning, implementing, concluding and reporting). In this stage, the questioning was initiated by the teacher, while planning, implementing, concluding and reporting were carried out by the students. Students worked in small groups where they discussed their inquiry plan. Before conducting the investigation, students discussed their investigation plan with the teacher. They also discussed the results within their own group before making a report. Such an approach is warranted because the dynamics of group work can stimulate and sustain inquiry in many situations better than individual work ( Chiappetta \& Koballa, 2006) and also enhances students' problem-solving skills as well as concept development (Lumpe, 1995).

Phase 3. Class Discussion. This stage was intended to encourage students to explain their possible solutions or answers with reference to a particular activity. Students exchanged their ideas with other groups through class presentations. The teacher guided students' discussion by asking questions for justification (evidence) and clarification from students and used students' previous experiences as the basis for explaining concepts.

Phase 4. Application. In this stage students applied or extended their concepts or skills built from previous activities to a new but similar situation related to their daily lives and environmental issues. For example, students were asked to investigate whether materials around their home could be classified as acids or bases. They also had to set up an inquiry plan and conduct investigations using inquiry skills previously learned.

A summary of the intervention instructional program is provided in Appendix A in the Electronic Supplementary Materials (ESM) system of the journal. In addition, photographs showing the teacher and students in the different phases of the DSCI are shown in Appendix B in the ESM.

The quantitative dimension of the study

The quantitative research consisted of a quasi-experimental design that incorporated the following: 
(1) An achievement test on acids and bases (completed in about 45 minutes). This test (see Appendix C in the ESM) was administered to both the experimental and comparison groups as a pretest before their study of the acids and bases topic to ascertain their prior knowledge and understasnding of the related concepts. The test was administered again to both groups as a posttest after they had finished studying the topic on acids and bases. The test was developed by the researchers and consisted of both open-ended and multiple-choice questions. The content of the test was determined from curriculum guidelines, lecture materials, and chemistry textbooks, which cover the major concepts of acids and bases (i.e., characteristics, definitions, strength of acids and bases, neutralization, and $\mathrm{pH}$ ). Apart from identifying the efficacy of the intervention program, the test enabled us to identify any misconceptions about acids and bases that are documented in the research literature (Kousathana, Demerouti, \& Tsaparlis, 2005). The concepts that were investigated and the corresponding question numbers in the test are summarised in Table 1 . The test was evaluated by two experts in chemistry education and was not perceived to favour inquiry or traditional teaching approaches. The internal consistency reliability of this test was measured using Cronbach's alpha (Fraenkel \& Wallen, 2006) and was found to be 0.79 for both the pretest and the posttest.

Table 1 Concepts investigated in the achievement test on acids and bases

\begin{tabular}{lll}
\hline No & \multicolumn{1}{c}{ Concepts } & \multicolumn{1}{c}{$\begin{array}{c}\text { Question } \\
\text { numbers }\end{array}$} \\
\hline 1 & Characteristics of acids and bases & $1,5, \& 8$ \\
2 & Definition of acids and bases & $6 \& 10$ \\
3 & Strength of acids and bases & $2,9, \& 12$ \\
4 & Neutralization & $4 \& 7$ \\
5 & $\mathrm{pH}$ & $3 \& 11$ \\
\hline
\end{tabular}


2) A self-evaluation questionnaire on students' perceptions of their competence and confidence in carrying out the inquiry activities (completed in about 15 minutes). This questionnaire was administered to the experimental group on completion of the intervention program. The purpose of this questionnaire was to explore students' perceptions of their engagement and competence in doing inquiry activities. This questionnaire, adapted from Llewellyn (2002), consisted 13 statements to which students responded on a Likert-type scale with four options: 4 = always, 3 = often, 2 = sometimes, and $1=$ rarely. The competencies evaluated by the questionnaire are listed in Table 2, and the instrument is found in Appendix C in the ESM. The internal consistency reliability of the questionnaire using Cronbach's alpha (Fraenkel \& Wallen, 2006) was 0.78.

Table 2. Competencies investigated by the self-evaluation questionnaire

\begin{tabular}{lll}
\hline No & \multicolumn{1}{c}{ Competencies } & \multicolumn{1}{c}{ Question numbers } \\
\hline 1 & Collaboration and participation & $4,5,6,10, \& 11$ \\
2 & Competence in investigative activities & $1,2,3, \& 8$ \\
3 & Confidence in public presentation & $12 \& 13$ \\
4 & Resource use in investigations & $7 \& 9$ \\
\hline
\end{tabular}

The qualitative dimension of the study

An open-ended questionnaire on students' perceptions of the instructional process using the DSCI on acids and bases (completed in about 10 minutes). This questionnaire was administered to the experimental group after students had completed the intervention program. The questionnaire comprised three questions:

1. Do you consider that the activities on acids and bases that you have experienced are enjoyable? (Yes/No). Give reasons for your answer.

2. Do you believe that your understanding of acids and bases has improved through the teaching-learning method you have experienced? (Yes/No). Give reasons for your answer. 
3. What do you think is the best way to teach chemistry so that you are able to understand chemistry concepts better? Give reasons for your answer.

\section{Data analysis}

Quantitative data consisted of comparison of pretest and posttest scores on the achievement test on acids and bases for both the experimental and comparison groups. In addition, mean scores were computed for each of the four competencies of the self-evaluation questionnaire on students' perceptions of their competence and confidence in carrying out the inquiry activities. Qualitative data consisted of categorization of students' responses to the open-ended questionnaire on their perceptions of the instructional process using the DSCI on acids and bases.

To answer the first research question (Is the teaching innovation on acids and bases more effective in increasing students' cognitive achievement than traditional instruction?), the effect of the intervention program was examined by statistically analysing the pretest and posttest mean scores of the experimental and comparison groups (using SPSS software version 17). A one-way analysis of covariance (ANCOVA) was conducted using the pretest scores as covariate followed by an independent sample t-test of the mean gain scores.

To answer the second research question (What are students' perceptions on their engagement and competence in doing inquiry activities in the teaching innovation on acids and bases?), students' self-evaluation mean scores of the four competencies were analysed.

The third research question (What are students' perceptions of the instructional process in the teaching innovation on acids and bases?) was evaluated using three questions that were posed to the students. Their perceptions of the instructional process were grouped into five categories for the first two questions and into six categories for the thrird question. To check the reliability of the various categories, students' responses were independently coded by the first author and a colleague. In 95\% of cases, students' responses matched the relevant 
categories. All initial disagreements were resolved through discussions. Each category chosen by at least five students of the sample is presented and discussed in the results section below.

\section{Results}

The effect of the instructional innovation on students' achievement

In response to resesearch question 1, (Is the teaching innovation on acids and bases more effective in increasing students' cognitive achievement than traditional instruction?), a one-way between groups analysis of covariance (ANCOVA) was conducted to evaluate the effectiveness of the designed instructional intervention program in facilitating understanding of acid-base concepts among the grade 11 students. The independent variable was the grouping (experimental and comparison groups) while the dependent variable was the mean total score on the posttest. The mean total score in the pretest was used as the covariate in the analysis. There was a statistically significant difference between the two groups on the posttest mean scores $[\mathrm{F}(1,71)=71.67, p=0.00$; experimental group: $\mathrm{M}=40.69, \mathrm{SD}=4.39$; comparison group: $\mathrm{M}=32.08, \mathrm{SD}=4.33$ ]. In addition, an independent samples t-test conducted to compare the mean gain scores (difference between the prestest and the posttest scores) of the two groups showed a statistically significant difference in the mean gain scores between the experimental group $[\mathrm{M}=14.50, \mathrm{SD}=5.98]$ and the comparison group $[\mathrm{M}=6.95, \mathrm{SD}=5.31$; $\mathrm{t}(72)=5.75, p=0.00]$. It may be concluded from the above results that the instruction based on constructivist, inquiry-based, context-based approaches in the designed instructional program significantly improved overall students' understanding of acid-base concepts compared to the traditional teaching method.

It was mentioned previously that the 12 items in the achievement test were classified under five conceptual categories namely, (1) Characteristics of acids and bases, (2) Definition of acids and bases, (3) Strength of acids and bases, (4) Neutralization, and (5) pH. In order to 
compare the total mean scores between the two groups for each of the conceptual categories, additional one-way between groups analyses of covariance (ANCOVA) were conducted using the grouping as the independent variable, the posttest mean scores as the dependent variable and the pretest mean scores as the covariate in each case. With the exception of conceptual category 2 (Definition of acids and bases), there was significant difference in the mean scores between the experimental and comparison groups (see Table 3).

Table 3 ANCOVA comparisons of the five conceptual categories in the achievement test

\begin{tabular}{|c|c|c|c|c|}
\hline \multirow[b]{2}{*}{ Conceptual categories } & \multicolumn{2}{|c|}{ Posttest mean scores } & \multirow{2}{*}{ F values } & \multirow[b]{2}{*}{$\begin{array}{l}\text { Partial } \\
\text { eta } \\
\text { squared }\end{array}$} \\
\hline & $\begin{array}{c}\text { Experimental } \\
\text { group } \\
(\mathrm{n}=36)\end{array}$ & $\begin{array}{c}\text { Comparison } \\
\text { group } \\
(\mathrm{n}=38)\end{array}$ & & \\
\hline $\begin{array}{l}\text { 1) Characteristics of acids } \\
\text { and bases }\end{array}$ & 25.94 & 21.45 & $47.09^{* *}$ & 0.40 \\
\hline $\begin{array}{l}\text { 2) Definition of acids and } \\
\text { bases }\end{array}$ & 4.64 & 4.37 & 1.91 & 0.03 \\
\hline $\begin{array}{l}\text { 3) Strength of acids and } \\
\text { bases }\end{array}$ & 5.75 & 3.63 & $20.42 * *$ & 0.22 \\
\hline 4) Neutralization & 2.39 & 1.42 & $7.90 *$ & 0.10 \\
\hline 5) $\mathrm{pH}$ & 1.97 & 1.21 & $14.12 * *$ & 0.17 \\
\hline
\end{tabular}

Students' perceptions of their engagement and competence in doing inquiry activities

Student's perceptions of their engagement and competence in doing inquiry activities, solicited using the self-evaluation questionnaire (see Appendix D in the ESM), were analysed in order to respond to research question 2 (What are students' perceptions of their engagement and competence in doing inquiry activity in the teaching innovation on acids and bases?).

These students' perceptions were used to explain students' situational interest, which is a form of intrinsic motivation towards the learning environment (Palmer, 2009; Zusho, Pintrich, \& Coppola, 2003). Thus, the analysis of quantitative data on the self-evaluation questionnaire provided some information about motivation (i.e., intrinsic motivation) of students in the 
experimental group. The results of students' responses to the questionnaire are summarised in Table 4. Students' responses are presented in two categories: the positive category that included 'always' (code 4) and 'often' (code 3) responses, and the negative category that included 'sometimes' (code 2) and 'rare' (code 1) responses.

Table 4 Analysis results for each component in the self-evaluation questionnaire $(n=36)$

\begin{tabular}{cllccc}
\hline \multirow{2}{*}{ No } & \multirow{2}{*}{ Component } & \multicolumn{2}{c}{ Category } & & \\
\cline { 3 - 4 } & & Positive & Negative & M & SD \\
& & $(\%)$ & $(\%)$ & & \\
\hline 1 & Collaboration and participation & 73.3 & 26.7 & 3.22 & 0.40 \\
2 & Competence in investigative activities & 81.3 & 18.7 & 3.22 & 0.52 \\
3 & Confidence in public presentation & 65.3 & 34.7 & 3.01 & 0.85 \\
4 & Resource use in investigations & 31.9 & 68.1 & 2.28 & 0.76 \\
\hline
\end{tabular}

The data suggest that students were generally positive about their collaboration and participation in the inquiry activity, their competence in investigative activities, and their confidence in public presentation, but not about their use of resources in investigations. Students' perceptions regarding their engagement and competence in inquiry activities (i.e., components 1,2 , and 3$)$ ranged from a mean of 3.01 to a 3.22 on a 4 -point rating scale $(4=$ always, $3=$ often, $2=$ sometimes, and $1=$ rare). Component 4 had a mean of 2.28 . Thus, it appears that students believed they engaged fully in the inquiry tasks, felt very competent in doing the activities, and were very confident in public presentations.

Science educators believe that motivation (e.g., intrinsic motivation) can be discerned through students' reports of their beliefs on the level and quality of task engagement and confidence in performing a task (Zusho, Pintrich, \& Coppola, 2003). Furthermore, motivation and engagement are essential for effective learning (Blumenfeld, Kempler, \& Krajcik, 2006). Thus, results of the self-evaluation questionnaire, that were generally very positive, can be 
viewed as an indication that students' intrinsic motivation towards the learning environment was fairly high, and this condition can lead to more effective learning.

Students' perceptions of the instructional process in the DSCI

Students' perceptions of the instructional process were assessed by means of their responses to three questions. For question 1 (Do you consider that the activities on acids and bases that you have experienced are enjoyable? Give reasons for yor answer.), almost all students (35 students) in the experimental group said that they enjoyed the lessons. Only one student did not enjoy it. Students' reasons for claiming to enjoy the lessons are presented in Table 5, which shows four types of responses that were given by at least five students. It seems that students enjoyed the lessons because they involved many activities, were related to daily life, and made understanding of the topic easier, unlike lessons that used ordinary teaching methods.

For question 2 (Do you believe that your understanding of acids and bases has improved through the teaching-learning method you have experienced? Give reasons for your answer.), almost all students (35 students) in the experimental group said that their understanding of acids and bases had improved. Only one student said that her understanding of the concepts had not improved. Three types of responses suggesting that their understandings had improved were proferred by at least five students (see Table 5). It appears that students felt satisfied about their learning because they engaged actively in practical activities and collaborative work and these activities helped them in understanding the concepts of acids and bases.

Question 3 (What do you think is the best way to teach chemistry so that you are able to understand chemistry concepts better? Give reasons for your answer.) was intended to ascertain whether or not students preferred the teaching innovation in the lesson on acids and bases over the method they were used to. For this question, three reasons were chosen by at least five students (see Table 5). Most of the students liked this teaching innovation and prefered 
conducting more experiments, but some of them liked the lessons explained to them step by step (i.e., more structured).

Table 5 Distribution of students' reasons to questions 1, 2, and 3 (Research question 3)

\begin{tabular}{llc}
\hline Questions & Types of students' reasons & $\begin{array}{c}\text { Number of students } \\
\text { providing }\end{array}$ \\
& & 11 \\
Question 1: & A lot of practical activity & 7 \\
Enjoyment of & Relates to daily life & 10 \\
lessons & Makes the topic easy to understand & 5 \\
& Interesting and different from the usual method & 2 \\
Question 2: & Enjoyable & Practical activity makes the topic easy to \\
Improving their & understand and to remember & 14 \\
understandings of & The teaching method makes us share ideas/think \\
acids and bases & The teaching method is interesting and makes & 15 \\
& students more active & 5 \\
& The concept maps make the topics easy to & 1 \\
Question 3: The & understand & The method is appealing \\
best way to teach & Conduct more experiments & 10 \\
chemistry & The teacher provides explanations step by step & 13 \\
& Encourage reading textbooks and conducting & 6 \\
& experiments & Students will be more active and involved \\
& Having discussions with the teacher's guidance & 2 \\
\hline
\end{tabular}

In summary, almost all students in the experimental group enjoyed the lessons and felt that their understanding of acids and bases had improved, which indicated positive outcome expectations. Some students believed that the best way to teach chemistry involved the teaching innovation designed in this study, while others enjoyed the practical activities. It appears that the learning environment designed in the DSCI teaching innovation increased students' enjoyment, their perceptions of improved progress and they were more satisfied with their learning. According to Bandura (1997), increased self-efficacy and positive outcome expectations raise intrinsic motivation and lead to further learning. Thus the results of students' 
perceptions of the teaching innovation are very positive and this indicates that the teaching innovation can lead to effective learning (Ainley, 2004).

\section{Discussion}

The results of this study show that although students' posttest mean scores were not very high (experimental group: $M=26.19$ for pretest, $M=40.69$ for posttest; comparison group: $M=$ 25.13 for pretest, $\mathrm{M}=32.08$ for posttest; maximum possible score $=60$ ), the $D S C I$ has been effective in facilitating understanding of acid-base concepts. The experimental group significantly outperformed the comparison group in understanding the key concepts of acids and bases even though there is more room for further improvement of learning. The effectiveness of this instruction is also supported by students' increased intrinsic motivation as shown by (1) students' positive perceptions of their engagement and competence in doing inquiry activities, (2) students' positive perceptions of their learning environments (i.e. they enjoyed and liked the learning environment), and (3) their positive outcome expectations.

The possible reason for the observed difference between the experimental and the comparison groups lies in the different approaches of acquiring knowledge and understanding in chemistry. The teaching innovation designed in this study incorporated constructivist, inquiry, and context-based approaches. These approaches formed a coherent package that integrated key ideas in a way in which the approaches cannot really be separated. What this means is that constructivist ideas suggest using the inquiry method as students explore ideas, while the use of context allows for meaningful learning based on connecting concepts with everyday experiences. Thus, the teaching innovation (see Appendix A in the ESM) promotes students' active engagement in collaborative conceptual exploration, which includes contextually relevant ideas, within an inquiry framework. Moreover, the teaching innovation provides a learning environment which integrated hands-on inquiry activities and real-world applications, which can stimulate students' situational interest (i.e., a form of intrinsic 
motivation). Motivation and engagement are essential for effective learning. If students are placed and engaged in an environment in which they can actively connect the instruction to their interests and present understandings and have an opportunity to experience collaborative scientific inquiry, then achievement will be enhanced (Wise, 1996).

\section{Implications for Chemistry Teaching}

The teaching innovation that was used in this study would be of particular interest not just to chemistry teachers in Indonesia; the approach could be relevant in teaching acid-base concepts to any group of students in other countries as well. An important issue arising from this study is that effective inquiry teaching can be implemented with classs sizes from 35 - 40 students. The items that were used in the achievement test assessed the basic concepts necessary for understanding about acids and bases and, as stated previously, were deemed not to be designed to favour one group more than the other. Apart from acquiring factual knowledge, several of the questions require students to display understanding of particular concepts. Furthermore, the concepts that were assessed are likely to be included in most school science curricula.

In the Indonesian context, efforts to improve present and future science teachers' attitudes toward using inquiry as suggested by the new 2006 curriculum are of particular importance and are seen as the precursor of more effective chemistry instruction. Although the essence of inquiry teaching is not always easy to grasp and implementation has been proven difficult (Deboer, 2006), the inquiry-based pedagogy, underpinned by constructivist and context-based approaches designed in this study, has proven its potential to enhance student learning and motivation. Thus, when chemistry teachers intend to implement this kind of teaching innovation, they need to consider some practical issues. They must be willing to devote a great deal of time for preparation and implementation, must determine which topics in the curriculum other than acids and bases are appropriate to support this teaching innovation, and must be able to appropriately relate the teaching innovation to the relevant teacher-directed 
activities. Finally, the insights gained from this research could be used as a basis for organising professional development workshops for both preservice and inservice chemistry teachers.

\section{References}

Abd-El-Khalick, F., Boujaoude, S., Duschl, R., Lederman, N. G., Mamlok-Naaman, R. Hofstein, A., Niaz, M., Treagust, D., \& Tuan, H-L. (2004). Inquiry in science education: International perspectives. Science Education, 88, 397-419.

Ainley, M. (2004, November). What do we know about student motivation and engagement? Paper presented at the annual meeting of the Australian Association for Research in Education, Melbourne, Australia.

Bandura, A. (1997). Self-efficacy: The exercise of control. New York: W. H. Freeman and Company.

Bass, J. E., Constant, T. L., \& Carin, A. A. (2009). Methods for teaching science as inquiry (10th ed.). Boston, MA: Allyn \& Bacon.

Berg, K. C. (2006). The status of constructivism in chemical education research and its relationship to the teaching and learning of the concept of idealization in chemistry. Foundations of Chemistry, 8, 153-176.

Blumenfeld, P. C., Kempler, T. M., \& Krajcik, J. S. (2006). Motivation and cognitive engagement in learning environments. In R. K. Sawyer (Ed.), The Cambridge handbook of the learning science (pp 475-488). New York: Cambridge University Press.

Carey, S. (1985). Conceptual change in childhood. Cambridge, MA: MIT Press.

Chiappetta, E. L., \& Koballa, T. R. (2006). Science instruction in the middle and secondary schools: Developing fundamental knowledge and skills for teaching (6th ed.). Upper Saddle River, NJ: Prentice Hall.

Creswell, J. W. (2008). Educational research: Planning, conducting, and evaluating quantitative and qualitative research (3rd ed.). Upper Saddle River, NJ: Prentice Hall. 
Deboer, E. G. (2006). Historical perspective on inquiry teaching in schools. In L. B. Flick and N. G. Lederman (Eds.). Scientific inquiry and nature of science (pp. 17-35). Dordrecht, The Netherlands: Springer.

Fraenkel, J. R., \& Wallen, N. E. (2006). How to design and evaluate research in education (6th ed.). New York: McGraw-Hill.

Germann, P. J., \& Aram, R. J. (1996). Student's performances on the science processes of recording data, analyzing data, drawing conclusions, and providing evidence. Journal of Research in Science Teaching, 33(7), 773-798.

Germann, P. J., Haskins, S., \& Auls, S. (1996). Analysis of nine high school biology laboratory manuals: Promoting scientific inquiry. Journal of Research in Science Teaching, 33(5), 475-499.

Gilbert, J. K. (2006). On the nature of 'context' in chemical education. International Journal of Science Education, 28(9), 957-976.

Gonzales P., Calsyn, C., Jocelyn L., Mak K., Kastberg D., Arafeh S., Williams T., \& Tsen, W. (2000). Pursuing excellence: Comparisons of international eighth-grade mathematics and science achievement from a U.S. perspective, 1995 and 1999 (NCES 2001-028). Washington, DC: U.S. Department of Education, National Centre for Education Statistics. Retrieved November 15, 2008, from http://nces.ed.gov/timss/timss-r.

Hughes, G., \& Hay, D. (2001). Use of concept mapping to integrate the different perspectives of designers and other stakeholders in the development of e-learning materials. British Journal of Educational Technology, 32(5), 557-569.

Kousathana, M., Demerouti, M., \& Tsaparlis, G. (2005). Instructional misconceptions in acidbase equilibria: An analysis from a history and philosophy of science perspective. Science \& Education, 14, 173-193 
Lemke, M., Sen, A., Pahlke, E., Partelow, L., Miller, D., Williams, T., Kastberg, D., \& Jocelyn, L. (2004). International outcomes of learning in mathematics literacy and problem solving: PISA 2003 results from the U.S. perspective (NCES 2005-003). Washington, DC: U.S. Department of Education, National Centre for Education Statistics.

LeRoy, K., \& Lee, O. (2008). What research says about science assessment with english language learners. In Coffey, J., Douglas, R. and Stearns, C. (Eds), Assessing science learning: Perspective from research and practise (pp 341-355). Arlington, VA: National Science Teachers Association Press.

Liang, L. L., \& Gabel, D. L. (2005). Effectiveness of a constructivist approach to science instruction for prospective elementary teachers. International Journal of Science Education, 27(10), 1143-1162.

Llewellyn, D. (2002). Inquiry within: Implementing inquiry-based science standards. Thousand Oaks, CA: Corwin Press, Inc.

Loyen, S. M., \& Gijbels, D. (2008). Understanding the effects of constructivist learning environments: introducing a multi-directional approach. Instructional Science, 36, 351357.

Lumpe, A. T. (1995). Peer interaction in science concept development and problem solving. School Science and Mathematics, 96, 302-309.

National Education Standards Agency. (2007). Jakarta, Indonesia: BNSP

National Research Council. (1996). National science education standards. Washington DC: National Academy Press.

Palmer, D. H. (2009). Student interest generated during an inquiry skills lesson. Journal of Research in Science Teaching, 46 (2), 147-165.

Pintrich, P. R. \& De Groot, E. V. (1990). Motivational and self-regulated learning components of classroom academic performance. Journal of Educational Psychology, 82 (1), 33-40 
Pearsall, J. (1999). The concise Oxford dictionary. Oxford, UK: Oxford University Press.

Schwartz, A. T. (2006). Contextualized chemistry education: The American experiences. International Journal of Science Education, 28(9), 977-998.

Sidi, I. J. (2008, August). Synergy of curriculum and the national examination. Paper presented at National seminar on the national examination conducted by the Quality Insurance Board, Middle East of Java, Semarang, Indonesia. (see also http://sawali.info/2008/08/30/ujiannasional-un-jalan-terus/)

Spencer, J. N. (1999). New directions in teaching chemistry: A philosophical and pedagogical basis. Journal of Chemical Education, 76(4), 566-569.

Tashakkori, A., \& Teddlie, C. (2003). Handbook of mixed methods in social and behavioral research. Thousand Oaks, CA: SAGE Publications.

Trumbull, D. J., Bonney, R., \& Grudens-Schuck, N. (2005). Developing materials to promote inquiry: Lesson learned. Science Education, 89, 879-900.

Wise, K. C. (1996). Strategies for teaching science: What works? Clearing House, 69, 337-338.

Zusho, A., Pintrich, P. R., \& Coppola, B. (2003). Skill and will: the role of motivation and cognition in the learning of college chemistry. International Journal of Science Education, 25(9), 1081-1094. 
Click here to download supplementary material: ESM-12 September 2010.docx

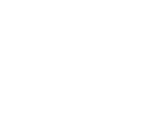

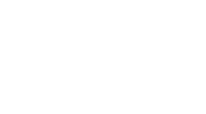
$\sqrt{2}$ (n) (1) (1) (1) . (n) (1) .

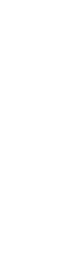
. 更 更 更 更 更 更 更 更 更 . (2) 